\title{
Modulation of the Pharmacological and Biochemical Actions of Leiurus quinquestriatus (L.q) Scorpion Venom by Exposure to Gamma Radiation
}

\author{
Heba A. Mohamed*, Esmat A. Shaaban*, Aber M Amin** and \\ Sanaa A. Kenawy \\ Department of Pharmacology and Toxicology - Faculty of Pharmacy- Cairo University \\ *Department of drug radiation research - National Center for Radiation Research and \\ Technology \\ **Department of labeled compound - Hot Lab Center \\ - Atomic Energy Authority
}

\begin{abstract}
Back ground

This study was undertaken to evaluate the effect of gamma radiation (1.5 KGy \& $3 \mathrm{KGy})$ on L.q scorpion venom. This was carried out by studying the toxicological, biochemical \& immunological properties of the venom before and after exposure to gamma radiation.
\end{abstract}

\section{Material and methods}

Animals, venom, antivenin, gamma radiation, ${ }^{125} \mathrm{I}$.

\section{Results}

Data revealed that the toxicity of irradiated venom (1.5 KGy \& $3 \mathrm{KGy})$ decreased as compared to that of the native one. $\mathrm{LD}_{50}$ of irradiated venom were $3.5 \mathrm{mg} / \mathrm{kg} \& 7.5 \mathrm{mg} / \mathrm{kg}$ respectively while, that of the native venom was $(0.39 \mathrm{mg} / \mathrm{kg})$. Moreover, the distribution of ${ }^{125}$ I-labeled L.q venom was studied in male Swiss mice tissue using chloramine-T method by being injected intravenously. At various time intervals, urine and blood were collected and the animals were sacrificed. Brain, lungs, heart, liver, kidneys, spleen, intestine, bone and muscle were isolated in order to determine the radioactivity content. The highest contents of ${ }^{125} \mathrm{I}$-labeled L.q venom were found in the liver and kidney that were quickly excreted into the urinary tract. Trial to label irradiated ( $1.5 \& 3 \mathrm{KGy})$ L.q venom was unsuccessful due to its decomposition. For that reason the utilization of the labeled irradiated L.q venom is of no meaning. In immunodiffusion technique, both irradiated and native venoms exhibited prominent precipitin bands indicating high concentration of specific antibodies against polyvalent antivenin with venom. Furthermore, the effect of half the $\mathrm{LD}_{50}$ of native or irradiated (1.5 KGy) L.q venom was studied on the activities of certain enzymes: ASAT, ALAT, LDH, CPK, CPK-MB, and the levels of total cholesterol, triglyceride, HDL-cholesterol, LDL-cholesterol and the oxidative stress biomarkers (plasma MDA \& blood GSH). Biochemical measurements showed that scorpion venom envenomation caused significant ( $\mathrm{p}<0.05$ ) elevation in serum ASAT, ALAT, LDH, CPK as well as CPK-MB activities, blood GSH level while, caused significant $(\mathrm{p}<0.05)$ reduction in triglyceride, HDL-cholesterol. In contrast, the $1.5 \mathrm{KGy}$ gamma irradiated L.q venom showed no alterations except in HDL-cholesterol that significantly decreased compared to that of the non-envenomated normal rats.

\section{Conclusion}

These results indicated that $1.5 \mathrm{KGy}$ gamma irradiation of venom offer an effective method for reducing the toxic effect of venom.

Key words: gamma radiation, Leiurus quinquestriatus scorpion venom (L.q), $\mathrm{LD}_{50},{ }^{125} \mathrm{I}$-labeled L.q, double immunodiffusion, liver and cardiac enzymes, lipid profile, oxidative stress biomarkers. 



\section{Introduction}

The deathstalker (Leiurus quinquestriatus), is a species of scorpion, a member of the family Buthidae that belongs to the phylum arthropoda class arachnida (Bucherl, 1971). It is also known as Palestine yellow scorpion, Omdurman scorpion and Israeli desert scorpion (Werness et al., 2004; Minton et al., 2010). The deathstalker is a highly dangerous species because its venom is a powerful cocktail of neurotoxins, with a low $\mathrm{LD}_{50}$. Unlike snakes, all scorpions are venomous.

Ejecting the venom following a scorpion sting is extremely painful. The venom ejection is violent and rapid, but normally would not kill healthy adult human. However, young children, the elderly, or infirm (such as those with a cardiac disorder or those who are allergic) would be at much greater risk. Any envenomation runs the risk of anaphylaxis, a potentially life-threatening allergic reaction to the venom. If a sting from L.q does prove fatal, the cause of death is usually pulmonary edema.

Fischer and Bohn, (1957), found that scorpion venom is composed of several proteins and enzymes that have known neurotoxic, cardiotoxic, nephrotoxic, and hemotoxic effects. The toxic proteins in scorpion venom consist of a single polypeptide chain, cross linked by four disulfide bridges. The location of the disulfide bridges in scorpion toxin is quite different from that in snake toxins. Scorpion venom is a highly antigenic compound. Treatment of patients with systemic symptoms should be initiated as soon as possible. Since the lethal dose is measured in milligrams injected per kilogram of body weight of the victim; thus, lower body weight is related to increased morbidity and mortality. Most reported deaths occur within $24 \mathrm{~h}$ and are related to respiratory and cardiovascular collapse. Most investigators believe that the antivenin should be administered immediately after scorpion sting, otherwise the venom will produce irreversible lesions (Balozet, 1971).

Irradiation of proteins in either dry state or aqueous solution has been shown to cause a decrease and loss of biological properties as the enzymatic activities, hormonal and toxic features while the immunological functions of proteins may not be affected (Skalka and Antoni, 1970).

\section{Material and Methods}

\section{Animals}

White male Swiss albino mice, weighing 20$25 \mathrm{~g}$ and 30-35 $\mathrm{g}$ were used for $\mathrm{LD}_{50}$ study and experiments of iodinated venom respectively. Adult male Wistar albino rats, weighing 120$150 \mathrm{~g}$, were also used. Mice \& rats were obtained from the Institute of Ophthalmology (Giza, Egypt). The animals were kept under suitable laboratory conditions throughout the period of investigation. They were allowed free access to food consisting of standard pellets obtained from El-Nasr Chemical Company (Cairo, Egypt) and water ad libitum. The study was carried out according to the approval of Ethics Committee for Animal Experimentation at Faculty of Pharmacy, Cairo University and in accordance with the guidelines set by the EEC regulations (revised directive 86/609/EEC) at the National Center for Radiation Research and Technology.

\section{Venom}

L.q venom was obtained from laboratory unit of Medical Research Center, Faculty of Medicine, Ain Shams University.

\section{Antivenin}

Egyptian polyvalent antivenin prepared against scorpion venom was used. It was obtained from the Egyptian Organization of Biological Products and Vaccines (VACSERA), Agouza, Cairo, Egypt. The polyvalent antivenin produced in horses was kept at $4^{\circ} \mathrm{C}$ till used.

\section{Radioactive material}

${ }^{125}$ I was purchased from Radiochemical Center-Amersham-England diluted with $\mathrm{NaOH}$ when required (Specific Activity $=15.5$ $\mathrm{mCi} / \mu \mathrm{g})$.

\section{Irradiation of the venom}

The venom was irradiated with $1.5 \mathrm{KGy}$ and 3 KGy gamma rays in the National Center for Research and Radiation Technology, Cairo, Egypt; using acobalt-60 gamma cell 220, manufactured by the Atomic Energy of Canada (AECL). The radiation dose rate was $1.42 \mathrm{~Gy}$ per second. 
In this study, a saline solution of L.q venom was subjected to integral radiation dose levels of 1.5 and $3 \mathrm{KGy}$.

\section{Lethality}

$\mathrm{LD}_{50}$ of L.q venom was determined before and after exposure to $1.5 \mathrm{KGy}$ or $3 \mathrm{KGy}$ gamma radiation according to the method of Spearman and karber (Finney, 1964).

\section{Immunogenicity}

Double immunodiffusion experiments were carried-out as described by Ouchterlony, (1948).

\section{Iodination of scorpion venom}

Iodination of scorpion venom was carried out according to the method of Hunter and Greenwood, (1962). In a $1 \mathrm{ml}$ volume reaction vial, that is tightly closed by a screw cap, contains $200 \mu \mathrm{l}$ of phosphate buffer $0.2 \mathrm{M}$, $\mathrm{pH}=7$, a suitable amount of venom $(200 \mu \mathrm{g})$ was placed and an appropriate quantity of chloramine- $\mathrm{T}(0.87 \mathrm{Mm})$, (freshly prepared in water ) was added. For labeling the previous solution $10 \mu \mathrm{l}$ of $\mathrm{Na}^{125} \mathrm{I}$ (3-5MBq) was added and then the reaction mixture was kept in a room temperature for $30 \mathrm{~min}$. The reaction was quenched by the addition of sodium metabisulphite.

\section{Determination of radiochemical yield}

The radiochemical yield and the in-vitro stability of ${ }^{125}$ I-venom were determined using instant thin layer chromatography (ITLC) according to the method described by Asikoglu et al. (2000).

Radiochemical yield \% = activity of labeled

product/Total activity $\mathrm{X} 100$

\section{Determination of radiochemical purity}

The radiochemical purity and the in-vitro stability of ${ }^{125} \mathrm{I}$-venom were determined using electrophoresis technique by cellulose acetate strips according to the method of Milan bier, (1959).

\section{In-vitro stability of the ${ }^{125}$ I-labeled scorpion venom}

The in-vitro stability of the ${ }^{125} \mathrm{I}$-labeled venom was studied. The reaction mixture was prepared with the conditions which gave the best radiochemical yield, and applying a spot of the labeled mixture on a thin layer chromatography (TLC) at different time intervals $(1,2,4,8,12,24 \mathrm{~h})$ after labeling, then chromatography was carried out.

\section{In-vivo biodistribution of ${ }^{125}$ I-labeled scorpion venom in mice}

Studies of organ distribution were carried out in a group of three male albino mice. Each animal was injected in the tail vein with $0.2 \mathrm{ml}$ solution containing $3.7 \mathrm{MBq}$ of ${ }^{125} \mathrm{I}$-venom. The mice were put in metabolic cages for the recommended time then sacrificed. Time dependent pharmacokinetic studies were carried out at $10 \mathrm{~min}, 1 \mathrm{~h}, 2 \mathrm{~h}$, and $4 \mathrm{~h}$ post injection.

The organs as well as other body parts and fluids were prepared. Activity in each organ was counted and expressed as a percentage of the injected activity per organ. Blood, bone and muscles were assumed to be 7,10 and $40 \%$ of the total body weight respectively (Rhodes, 1974).

Correction was made for background radiation and physical decay during experiment.

$\%$ Uptake/ organ = Organ count $/ \mathrm{min}(\mathrm{cpm}) /$

Standard cpm x 100

\section{Experimental design}

Mice were used for in-vivo biodistribution ${ }^{125} \mathrm{I}$ labeled scorpion venom. Mice were classified into four groups, each group consists of 3 animals. Each animal was injected in the tail vein with $0.2 \mathrm{ml}$ solution containing $3.7 \mathrm{MBq}$ of ${ }^{125} \mathrm{I}$ - scorpion venom. Mice were put in metabolic cages for the recommended time then sacrificed. Time dependent pharmacokinetic studies were carried out at 10 min, $1 \mathrm{~h}, 2 \mathrm{~h}$, and $4 \mathrm{~h}$ post injection.

Half value of $\mathrm{LD}_{50}$ of native and $1.5 \mathrm{KGy}$ irradiated L.q venom were the selected doses to carry out the biochemical experiments of this study in rats.

Rats were classified into three sets, each consisting of 8 animals as follows:

Set 1: normal non-envenomated rats that received saline i.p and served as normal group.

Set 2: rats that received a single dose of native L.q venom $(0.197 \mathrm{mg} / \mathrm{kg}$ i.p) and served as native group.

Set 3: rats that received a single dose of irradiated (1.5 KGy) L.q venom $(1.758 \mathrm{mg} / \mathrm{kg}$ i.p) and served as irradiated group.

Blood samples $(2-3 \mathrm{ml})$ were collected by being withdrawn via the retro-orbital vein using heparinized capillary tubes at $0 \& 4 \mathrm{~h}$ following injection. The blood sample was divided into 3 
aliquots. The first part was used for estimation of MDA. The second part was collected in dry clean test tubes containing EDTA and left for $1 \mathrm{~h}$ then centrifuged at 3000 r.p.m at $4 \mathrm{C}^{\circ}$ for 15 minute to separate plasma to be used for determination of GSH level. The third part was left at room temperature for separation of serum and used for estimation of the cardiac enzymes, liver enzymes and lipid profile.

At the end of the experiment, animals were sacrificed by decapitation under anesthesia.

\section{Determination of blood lipid peroxides}

Lipid peroxidation products were estimated by determination of the blood level of thiobarbituric acid reactive substances (TBARS). It was determined according to the method of Yoshioka et al. (1979).

\section{Determination of blood glutathione (GSH)}

GSH in blood was determined according to the method described by Beutler et al. (1963).

Determination of serum alanine aminotransferase (ALAT) and aspartate aminotransferase (ASAT) activity

Activity of ALAT and ASAT was determined in serum. The colorimetric assay was performed using a test reagent kit according to the method of Tietz, (1976).

Determination of serum cholesterol and triglycerides concentration

Cholesterol concentration was determined according to the method of Ellefson and Carawy, (1976) while, triglycerides concentration was determined according to the method of Bucolo et al. (1973) both are enzymatic colorimetric test.

\section{Determination of serum HDL-cholesterol concentration}

HDL-cholesterol was determined according to the method of NCER, (1995).

\section{Determination of serum LDL-cholesterol concentration}

To calculate LDL cholesterol in mg/dl: LDL cholesterol concentration was calculated as follows:

LDL-cholesterol $=$ total cholesteroltriglycerides/5 + HDL-cholesterol.

Determination of serum creatine kinase (CK), serum isoenzyme creatine kinase-MB
(CK-MB) and serum lactate dehydrogenase activity (LDH)

Creatine kinase and creatine kinase-MB were determined according to the method of the IFCC, (1989) while lactate dehyrogenase was determined according to the method of Dito, (1979).

\section{Statistical analysis}

Comparison between different groups was carried out by one-way analysis of variance (ANOVA) followed by Tukey-Kramer multiple comparisons test using Instat software, version 3 (Graph pad Software, Inc., San Diego, USA).

The $\mathrm{p}$ value was set at $<0.05$.

\section{Results}

\section{Lethality}

$\mathrm{LD}_{50}$ for native (non-irradiated) L.q venom was estimated to be $0.394 \mathrm{mg} / \mathrm{kg}$. However, after irradiation of the L.q venom (1.5 KGy), the $\mathrm{LD}_{50}$ was $3.517 \mathrm{mg} / \mathrm{kg}$. Increasing the gamma radiation to $3 \mathrm{KGy}$, increased the $\mathrm{LD}_{50}$ to be $7.5 \mathrm{mg} / \mathrm{kg}$ table (1).

Thus, $\mathrm{LD}_{50}$ of L.q venom exposed $1.5 \mathrm{KGy}$ was increased 11 times the native one, while that exposed to $3 \mathrm{KGy}$ was increased 20 times its native venom.

\section{Double immunodiffusion technique}

Results of the double immunodiffusion test of native (non-irradiated), $1.5 \mathrm{KGy}$ and $3 \mathrm{KGy}$ gamma irradiated venom against a commercial polyvalent Egyptian antivenin, showed similar precipitin bands; the visible four distinct lines obtained in the immunodiffusion reactions were identical and joined smoothly at the corners, indicating that there was no change in the antigenic determinant figure (1).

In this study a dose of $1.5 \mathrm{KGy}$ gamma rays was selected, showing an effective detoxification (increase of $\mathrm{LD}_{50}$ ) for L.q venom, while maintaining their immunogenic properties.

\section{Iodination of scorpion venom}

1- Study of scorpion venom amount on the radiochemical yield (\%) of ${ }^{125}$ I-scorpion venom using chloramine-T as oxidizing agent 

showed that, increasing the amount of scorpion venom was accompanied by an increase in the radiochemical yield of ${ }^{125} \mathrm{I}-$ scorpion venom, where it reached $95.4 \%$ at $200 \mu \mathrm{g}$ of scorpion venom. By increasing the amount of scorpion venom above $300 \mu \mathrm{g}$, the radiochemical yield remained constant because the entire generated iodonium ions in the reaction were captured at that concentration of scorpion venom figure (2).

2- Chloramine- $T$ the strong oxidizing agent commonly used in the iodination of organic compounds was able to oxidize the $\mathrm{I}^{-}$to $\mathrm{I}^{+}$for electrophilic substitution in scorpion venom. Below $0.87 \mathrm{mM}$ chloramine- $\mathrm{T}$, the percent radiochemical yield of ${ }^{125} \mathrm{I}$-scorpion venom was low (85 \%) which may be due to the insufficiency of chloramine-T concentration to oxidize all the iodide ions present in the solution. Above $0.87 \mathrm{mM}$, chloramine-T concentration has little effect on the radiochemical yield of ${ }^{125} \mathrm{I}$-scorpion venom. The maximum yield of ${ }^{125}$ I-scorpion venom was obtained at $0.87 \mathrm{mM}$ chloramine-T under the conditions of the experiment. Increasing the amount of oxidizing agent above $0.87 \mathrm{mM}$ leads to a decrease in the radiochemical yield of ${ }^{125}$ I-melphalan due to the formation of undesirable oxidative side reactions like chlorination, polymerization and denaturation of substrate (Mcfarlane, 1958) as shown in figure (3).

3- The radiochemical yield of ${ }^{125} \mathrm{I}$-scorpion venom was found to be $68.6 \%$ at $25^{\circ} \mathrm{C}$ and increased to $75.6 \%$ and $96.4 \%$ on increasing the reaction temperature of the mixture to $40^{\circ} \mathrm{C}$ and $60^{\circ} \mathrm{C}$ respectively at $30 \mathrm{~min}$ reaction time. This is due to the fact that leaving hydronium ion required some energy to break the $\mathrm{C}-\mathrm{H}$ bond and to initiate the introduction of the radioactive iodonium ion into the scorpion venom. By raising the reaction temperature to $100^{\circ} \mathrm{C}$, decrease in the radiochemical yield of ${ }^{125}$ I-scorpion venom was observed indicating the instability of the labeled compound figure (4).

4- It is clear that the radiochemical yield of ${ }^{125}$ I-scorpion venom increased from $75.8 \%$ to $95.4 \%$ by increasing the reaction time from 5 $\min$ to $30 \mathrm{~min}$ at $60^{\circ} \mathrm{C}$. Extending the reaction time to $60 \mathrm{~min}$ caused slight decrease in the radiochemical yield of ${ }^{125}$ I-scorpion venom figure (5). This can be attributed to the long exposure of substrate (scorpion venom) to the oxidizing agent which causes oxidative side reactions like chlorination, polymerization and denaturation of substrate (Knust et al., 1990).

5- Figure (6) showed that at $\mathrm{pH} \mathrm{2,} \mathrm{the}$ radiochemical yield of ${ }^{125}$ I-scorpion venom was relatively low (63.7\%) as a result of the predominance of iodine monochloride $\mathrm{ICl}$ species which have lower oxidation potential than hypochlorus acid $\mathrm{HOCl}$ species (Cynthia et al., 1979) The maximum radiochemical yield of ${ }^{125}$ I-scorpion venom $(95.4 \%)$ was obtained around $\mathrm{pH}$ 7. The chloramine-T method has an optimum labeling efficiency at approximately $\mathrm{pH} 7$ and labeling efficiency is reduced at higher or lower $\mathrm{pH}$ values (Rayudu et al., 1983). By increasing the $\mathrm{pH}$ to 9 and 11, a decrease in the radiochemical yield of ${ }^{125} \mathrm{I}$ scorpion venom was observed. This may be attributed to the decrease in iodonium ion which is responsible for the electrophilic substitution reaction (Saccavini and Bruneau, 1984).

The optimum conditions for iodination of L.q scorpion venom were using $200 \mu \mathrm{g}$ of scorpion venom, $0.87 \mathrm{mM}$ chloramine- $\mathrm{T}$, at $60^{\circ} \mathrm{C}$, within 30 min reaction time and $\mathrm{pH} 7$.

\section{In -vitro stability of the ${ }^{125}$ I-labeled scorpion venom}

The in vitro stability of ${ }^{125} \mathrm{I}$-venom post labeling at time intervals $(1,2,4,8,12,24 \mathrm{~h})$ was shown in table (2). The ${ }^{125}$ I should be used during the first hour since stability was changed by time.

\section{Biodistribution of ${ }^{125}$ I-scorpion venom in different organs in normal mice}

When ${ }^{125}$ I-venom was injected in normal mice via intravenous route, the tracer was distributed all over the body organs and fluids. This route of biodistribution depends mainly on the ${ }^{125}$ I-venom compound. The activity in the stomach, urine, bone and intestine were 8.6, 12.2, 1.7 and $12.9 \%$ respectively. This suggests the rapid excretion of the labeled compound. Other organs activity were normal and did not show significant variation table (3).

All the obtained data demonstrated that the tracer was distributed rapidly throughout the body after intravenous injection (10 min), and cleared rapidly through the hepatobiliary system at $4 \mathrm{~h}$ post injection. The liver was the organ with the highest radioactivity that was quickly excreted into the intestinal tract. The presence of activity in the urinary bladder 
suggests the excretion of the tracer through the kidneys to some extent.

Trial to label irradiated (1.5 and 3 KGy) L.q venom was unsuccessful since its application on TLC resulted in different species due to its decomposition. For that reason the utilization of the labeled irradiated L.q venom is of no meaning.

Effect of native and gamma irradiated (1.5 KGy) L.q venom on plasma MDA and blood GSH in rats

Results showed that normal plasma MDA was unaffected by the native L.q venom. There was a significant decrease $(\mathrm{p}<0.05)$ of the plasma MDA by the $\gamma$-irradiated (1.5 KGy) L.q venom. However, blood GSH of the normal was significantly increased $(\mathrm{p}<0.05)$ by the native L.q venom, While There was unaffected by the $\gamma$-irradiated (1.5 KGy) L.q venom $4 \mathrm{~h}$ post injection with a dose equals to the half value of $\mathrm{LD}_{50}$ as seen in figure (7).

Effect of native and gamma irradiated (1.5 KGy) L.q venom on serum alanine aminotransferase (ALAT) and aspartate aminotransferase (ASAT) activity in rats

Results showed that both serum ALAT and ASAT of the normal was significantly increased ( $p<0.05$ ) by the native L.q venom but unaffected by the $\gamma$-irradiated (1.5 KGy) L.q venom $4 \mathrm{~h}$ post injection with a dose equals to the half value of $\mathrm{LD}_{50}$ as seen in figure (8).

Effect of native and gamma irradiated (1.5 KGy) L.q venom on serum lipid profile (cholesterol, triglyceride, HDL and LDL) in rats

Results showed that normal serum cholesterol and LDL-cholesterol were unaffected by the native L.q venom. Serum triglyceride and HDL-cholesterol of the normal was significantly decreased $(\mathrm{p}<0.05)$ by the native L.q venom, while, serum cholesterol, triglyceride and LDL-cholesterol were unaffected by the $\gamma$-irradiated ( $1.5 \mathrm{KGy}) \mathrm{L.q}$ venom but serum HDL-cholesterol of the normal was significantly decreased $(\mathrm{p}<0.05)$ by the $\gamma$-irradiated (1.5 KGy) L.q venom $4 \mathrm{~h}$ post injecting with a dose equals to the half value of $\mathrm{LD}_{50}$ as seen in figure (9).

Effect of native and gamma irradiated (1.5 KGy) L.q venom on serum cardiac enzymes (CK, CK-MB and LDH) activities in rats
L.q scorpion venom caused a significant increase $(\mathrm{p}<0.05)$ in serum CK, CK-MB and $\mathrm{LDH}$ compared to the normal nonenvenomated while, $\gamma$-irradiated $(1.5 \mathrm{KGy})$ L.q venom did not change serum $\mathrm{CK}$, CK$\mathrm{MB}$, LDH compared to the normal nonenvenomated value but caused significant decrease $(\mathrm{p}<0.05)$ in serum CK, CK-MB and LDH when compared to the native nonirradiated venom $4 \mathrm{~h}$ post injection with a dose equals to the half value of $\mathrm{LD}_{50}$ figure (10).

\section{Discussion}

In the current study the toxicity of the native L.q scorpion venom was reduced 11 and 20 times following the exposure to $1.5 \mathrm{KGy}$ and 3 KGy gamma rays respectively.

Thus, progressive increase in $\mathrm{LD}_{50}$ after gamma irradiation indicates decrease in toxicity of L.q scorpion venom. These results are in harmony with previously reported data (Bucherl, 1971; Shaaban, 1990 \& Fatani et al., 2010).

The effect of gamma irradiation on venom solution could be attributed mainly to its known effects on protein molecules, as venoms are mainly protein in nature. Ionizing radiation can change the molecular structure and the biological properties of protein molecules (Boni-Mitake et al., 2001). This can occur by two forms: direct process by which ionizing radiation interacts directly on target molecules and an indirect process by which the product generated by water radiolysis, like $\mathrm{e}^{-}, \mathrm{O}_{2}^{-}, \mathrm{H}^{+}$and $\mathrm{OH}^{-}$interact with target molecules and can modify the biological activity of protein and peptides by reacting with certain sites or groups in the molecule (Garrison, 1987 \& Casare et al., 2006).

The produced radicals act by removing hydrogen, breaking disulfide bonds, promoting deamination as well as inducing the formation of intramolecular and intermolecular covalent bonds (Halliwell \& Gutteridge, 1989). These structural changes result in a decrease or loss of the enzymatic and biological activities of the proteins (Gallacci et al., 2000).

Loss of function of protein by irradiation is not usually due to breaking peptide bonds, or otherwise, disrupting the primary skeletal structure of peptide chain. It may result from a break in the hydrogen or disulfide bonds 
which in turn can result in a disorganization of the internal relationships of side chain groups, or an exposure of amino-acid groups, resulting in change in biological activity (Hayes, 2001).

The toxicity of the venom from scorpions belonging to the family Buthidae, was known to be attributed to the effect of small proteins, with an approximate mol wt of 7000, containing 57-78 amino-acids, cross linked by four disulfide bridges (Zlotkin et al., 1978 \& Shaaban, 1990).

It was believed that, the effects of radiation could perhaps, lead to a break of the bridges, with the resultant attenuation of the toxicity of the venom. This finding was in agreement with that of Yang. (1970) who demonstrated the integrity of the disulphide bonds in cobrotoxin (toxic protein from Formosan cobra). The reduction of the disulphide bonds to sulphydryl, by B. mercapto ethanol, was leading to loss of toxicity of cobrotoxin.

It has been shown that gamma irradiation is an effective technique for attenuating venom toxicity and maintaining venom immunogenicity (Shaaban, 2003; Abib and Laraba-Djebari, 2003).

The present results showed that the antigenic response was not changed as judged by the capacity of irradiated venom to react with the antivenin. The immunodiffusion technique showed identity between native and irradiated samples. These results are in agreement with the data of other studies that reported that ionizing radiation is able to detoxify Androctonus amoreuxi without affecting the immunogenic properties (Shaaban, 1990).

The present radioiodination reaction of venom with iodine-125 was carried out using $200 \mu \mathrm{g}$ venom and $150 \mu \mathrm{g}$ chloramine- $\mathrm{T}$ at $60^{\circ} \mathrm{C}$ for 30 min. The maximum radiochemical capacity of ${ }^{125} \mathrm{I}$-venom yield was obtained around $\mathrm{pH} 7$. The optimum conditions were selected according to studies of several investigators (Mcfarlane, 1958; Rayudu et al., 1983; Saccavini and Bruneau, 1984 \& Knust et al., 1990)

Study of the distribution of ${ }^{125}$ I-labeled L.q venom showed the highest contents of radioactivity in liver and kidney. Radioactivity of the brain indicates that ${ }^{125} \mathrm{I}$-scorpion venom is stable in-vivo against biological decomposition.

In this study labeling irradiated (1.5 and 3 KGy) scorpion venom was unsuccessful. However, Boni-Mitake et al. (2006) successfully labeled both native and irradiated venom using modified method and study distribution of ${ }^{125}$ I-labeled crotamine in mice tissues. Both native and irradiated (2 KGy) proteins were labeled with ${ }^{125} \mathrm{I}$ using chloramines-T method after purified crotamine from venom by gel filtration followed by ion exchange chromatography, using a fast performance liquid chromatography (FPLC). Native and irradiated crotamine were rapidly absorbed and they appear to have hepatic metabolism and renal elimination. It is possible that the irradiated crotamine was metabolized and eliminated faster than the native crotamine, probably by means of structural alterations induced by gamma irradiation, which could possibly explain the reduced toxicity of the irradiated protein.

Moreover, it is documented that the cardiovascular effects are the major factors that may lead to death following both exipermental and human scorpion envenomation (Cupo and Hering, 2002). Even though the mechanism of venom -induced cardiovascular effects is strongly believed to be a consequence of the increase of neurotransmitter release evoked by the action of toxins on voltage-sensitive sodium channels (Rogers et al., 1996; Chen and Heinmann, 2001). The enzymes of the venoms were shown to be responsible for several observed biological, pharmacological and toxicological effects associated with the envenomation process (Kini, 1997).

The current experiments assessed the impact of gamma irradiation of L.q venom on the effects induced by the venom on certain oxidative stress biomarkers, liver enzymes, lipid profile \& cardiac enzymes. Exposure of scorpion venoms in aqueous solution to a dose of $1.5 \mathrm{KGy}$ gamma radiations was suitable for attenuating venom.

The present study revealed that native L.q venom caused no change in normal plasma MDA, while, there was a significant decrease of the plasma MDA by the $\gamma$-irradiated (1.5 KGy) L.q venom. These results agreed with those reported by Fatani et al. (2006) and Elalfy et al. (2007).

There are few reports on the effect of gamma rays on scorpion venoms concerning lipid peroxidation in general. The current study revealed that experimental envenomation by L.q venom was accompanied by free radical generation and depletion of antioxidant 

defense system. Such elevation in oxidative stress parameters correlate with the cardiac injury biochemical markers as well as hemodynamic manifestations following scorpion envenomation (El-alfy et al., 2007).

In vitro studies have shown a direct correlation between degree of lipid peroxidation and phospholipase $\mathrm{A}_{2}$-induced phospholipids hydrolysis (Sevanian et al., 1989). On the other hand, inhibition of phospholipase $\mathrm{A}_{2}$ significantly reduced lipid peroxidation (Borowitz et al., 1989). Phospholipids hydrolysis by $\mathrm{PLA}_{2}$ enzyme releases arachidonic acid, in turn its metabolism results in the formation of potentially toxic reactive oxygen species (ROS) and lipid peroxidation. Previous studies demonstrated the effect of gamma radiation on the Vipera lebetina and that phospholipase $\mathrm{A}_{2}$ activity was a bolished in the irradiated venom.

In the present study, normal blood GSH was significantly increased by the native L.q venom, while unaffected by the $\gamma$-irradiated (1.5 KGy) L.q venom. It seems probable that, these results might be a secondary event following the increase in lipid peroxides, as lipid peroxidation is seemingly an obligatory consequence of life which is compensated by the antioxidative defence systems which include; enzymes (glutathione peroxidase, superoxide dismutases and catalase) or low molecular compounds (ascorbic acid, carotinoids and tocopherols) (Nigam and Schewe, 2000).

Rats envenomated by native L.q venom exhibited marked depletion of glutathione peroxidase as well as glutathione reductase activities in cardiac tissue. Such decreased activity implicates low cardiac glutathione content, which is a key biomarker of oxidative stress (Meister and Anderson, 1983). Reduced GSH is an endogenous antioxidant that acts among the first line of defense system against pro-oxidant status (Halliwell and Gulteridge, 1999).

The activities of the present aspartate aminotransferase (ASAT), and alanine aminotransferase (ALAT) underwent a highly significant increase following envenomation with native L.q compared to the normal nonenvenomated due to the destruction of the hepatocytes as a result of venom injection accompined with disturbances in the hepatic functions of the envenomated animals through severe hepatocellular injuries and necrosis of hepatocytes. The serum transaminase level is most widely used as a measure of hepatic injury, due to its ease of measurement and high degree of sensitivity. It is useful for the detection of early damage of hepatic tissue and requires less effort than that required for a histologic analysis, moreover without sacrifice of the animals (Ray et al., 2006).

The results of ASAT and ALAT are in agreement with prior reports (El-missiry et al., 2010) that used Echis pyramidium venom. There was elevation in the serum concentration of ASAT, ALAT and ALP in animals four hours post envenomation in comparison with the control group. Also, Shaaban and Hafez. (2003) reported that intraperitoneal injection of sublethal dose of Naje haje venom in rats induced significant elevation in the activities of ASAT, ALAT and ALP as compared to control.

Native L.q venom caused significant decrease in serum triglyceride and HDL-cholesterol compared to normal non-envenomated. $\gamma$ irradiated (1.5 KGy) L.q venom significantly decreased serum HDL-cholesterol compared to normal non-envenomated and native nonirradiated scorpion venom but caused significant increase in serum total cholesterol and triglyceride compared to native nonirradiated scorpion venom value.

The variations in serum cholesterol and triglycerides observed after $4 \mathrm{~h}$ in the present study could be due to the damage of hepatocytes by the venom making them unable to phosphorylate the large amounts of fatty acids, together with the destruction of cell membranes of other tissues (El-Asmar et al., 1979) the results also suggest that those variations could be time dependent. The results are in agreement with a prior report (Ibrahim and AL-Jammaz, 2003) that used Echis coloratus venom. It has been found that there were changes in lipid profile levels in rats post envenomation in comparison with the control group.

Serotonin, which is present in high concentration in L.q scorpion venom (Adams and Weiss, 1959) is known to have a lipolytic effect through increasing cyclic AMP concentration (Levine et al., 1964). Scorpion venom was reported to release catecholamines (Henriques et al., 1968), these factors may cause lipolysis in the adipose tissues. The mobilization of the fatty acids from the 
adipose tissues may lead to their esterification in the liver with the formation of neutral fat and phospholipids. The free fatty acids liberated by the venom would result in an increased level of acetyl CoA (Ashmore and Weber, 1968). This increase could lead to an increase in the synthesis of cholesterol.

The present study indicated that the native L.q scorpion venom caused a highly significant increase of lactate dehydrogenase (LDH), creatine phosphokinase (CK), creatine phosphokinase isoenzyme (CK-MB) compared to the normal control. The obtained results are in agreement with those previously reported by other investigators (Sofer et al., 1991 \& Elmissiry et al., 2010). The enzymatic activity of CK-MB isoenzyme and total CPK were elevated following envenomation by the L.q venom in children. They speculated that the myocardial lesions are too small to cause heart failure in most cases, but they may account for the cardiovascular changes frequently seen in scorpion envenomation. This assumption was also confirmed by Shaaban and Hafez, (2003) who reported that the intraperitoneal injection of a sublethal dose of Naja haje venom in rats induced a significant elevation in the activities of $\mathrm{LDH}$ and $\mathrm{CPK}$ as compared to normal control.

Souza et al. (2002) investigated the ability of gamma radiation from ${ }^{60} \mathrm{Co}(2 \mathrm{KGy})$ to attenuate the toxic effects of Bothrops jararacussu venom on mouse neuromuscular preparations in vitro. It was concluded that ${ }^{60} \mathrm{Co}$ gamma radiation is able to abolish both the paralyzing and the myotoxic effects of Bothrops jararacussu venom on mouse neuromuscular junction. These findings support the hypothesis that gamma irradiation could be an important tool to improve antisera production by reducing toxicity while preserving immunogenicity.

Irradiation of crotoxin was shown to result in its aggregation and generation of low molecular weight breakdown products (Rogero and Nascimento, 1995). The aggregate presented no toxicity, no phospholipase activity and no ability to promote creatine kinase $(\mathrm{CPK})$ release into muscle tissue.

In conclusion, the present results indicated that L.q scorpion venom is a highly toxic venom. It produced a significant increase in oxidative stress biomarkers, liver enzymes, cardiac enzymes and lipid profile disturbance, whereas exposing venom to $1.5 \mathrm{KGy}$ gamma rays showed venom detoxification and loss of their biological properties without affecting their immunogenicity. Study of the distribution of ${ }^{125}$ I-labeled L.q scorpion venom showed the highest levels of radioactivity in liver and kidney. In addition, radioactivity of the brain indicates that ${ }^{125} \mathrm{I}$-scorpion venom is stable invivo against biological decomposition.

The present data revealed that, gamma irradiation of venom with $1.5 \mathrm{KGy}$ dose offer an effective method for reducing the chronic toxic effect of venom in immunized animal.

\section{References}

Abib H, Laraba-Djebari F, (2003): Effect of ${ }^{60} \mathrm{Co}$ gamma radiation on toxicity and hemorrhagic, myonecrotic and edema forming activity of Cerastes cerastes venom. Can. J.Physiol.Pharmacol., 81(12): $1125-1130$.

Adam K R, Weiss C, (1958): The occurrence of Shydroxytryptamine in scorpion venom. J. exp. Biol., 35: 39.

Ashmore J, Weber G, (1968): Hormonal control of carbohydrate metabolism in liver. $\mathrm{ln}$ : Carbohydrate Metabolism and Its Disorders, 1, 355, (Dickens, F., Randle, P. J. and Whelan, W. J., Eds.) . NewYork: Academic Press.

Asikoglu M, Yurt F, Cagliyan O, Unak P, Ozkilic H, (2000): Detecting inflammation with ${ }^{131}$ I-labeled ornidazole. Appl. Rad. Isot., 53: 411413.

Balozet L, (1971): Scorpionism in the old world. In: Venomous Animals, and their venoms, Vol. III, Venomous Invertebrates, (Bucherl, W. and Buckley, E., Eds.) New York: Academic Press. 349 - 367.

Beutler E, Duron O, Kelly B M, (1963): Improved method for the determination of blood glutathione. J. Lab. Clin. Med., 61: 882 - 888.

Boni-Mitake M, Costa H, Spencer P J, Vassilieff V S, Rogero J R, (2001): Effects of (60) Co gamma radiation on crotamine. Braz $\mathrm{J}$ Med Biol Res, 34: 1531 - 1538.

Boni-Mitake M, Costa H, Vassilieff V S, Rogero J R, (2006): Distribution of ${ }^{125}$ I-labeled crotamine in mice tissues. Toxicon, 48: 550 - 555.

Borowitz S, Montgomery C, (1989): Biochem. Biophys. Res. Commun., 158: 1021 - 1028.

Bucherl W, (1971): Classification, biology and venom extraction of scorpions. In: Venomous Animals, and their venoms, Vol. III, Venomous Invertebrates. Ed. Bucherl, W. and Buckley, E., New York: Academic Press. 317 - 347.

Bucolo G, David H, (1973): Quantitative determination of serum triglycerides by the use of the enzymes. Clinc Chem., 19: 475. 
Casare $M$ S, Spencer $\mathbf{P}$, Campos $\mathbf{L} \mathbf{A}$, Nascimento N, (2006): Study of gamma-radiation effects on crotamine and crotoxin. Journal of radioanalytical and Nuclear Chemistry, 269: 571 577.

Chen and Heinmann S H, (2001): Interaction of scorpion alpha-toxin with cardiac sodium channels: binding properties and enhancement of slow inactivation. J.Gen. Physiol., 117: 505 - 518.

Coenen H H, Moerlein S M, Stocklin G, (1983): Radiochem Acta. 34: 47 - 68.

Cupo P, Hering S E, (2002): Cardiac troponin I release after scorpion envenomating by Tityus serrulatus. Toxicon. 40: 823 - 830.

Cynthia B F, Roger K D, Kaumann A J, (1979): Theodore L.S., Lutz B; J. Mol. Pharmacol., 12: 328.

Dito W R, (1979): Lactate dehydrogenase, Abrief review. In: Griffiths JC, ed. Clinical Enzymology. New York: Masson Publishing USA; 1 - 8.

El-Asmar M F, Farag R M, Shoukry S, El-Shimi I R, (1979): Effect of Scorpion Leiurus quinquestriatus $\mathrm{H} \& \mathrm{E}$ Venom on Lipid Metabolism. Toxicon., 17: 279 - 283.

El-Alfy A T, Amany A E, Fatani A J, Kader F, (2007): Amelioration of the cardiovascular manifestations of the yellow scorpion Leiurus quinquestriatus envenomation in rats by red grape seeds proanthocyanidins. Toxicon., 51: 321 - 333.

Ellefson $R$ D, Caraway W T, (1976): Fundamentals of clinical chemistry. Ed Tietz NW; 506.

El-Missiry A G, Shaaban E A, Mohamed R M, Ahmed A A, Nadia M A, Manal I M, (2010): Influence of ionizing radiation on Echis Pyrimidium Snake Venom: Biochemical and Immunological Aspects. The Egyptian Journal of Hospital Medicine., 40: 314 - 334.

Fatani A J, Al-Zuhair H A, Yacoub H I, AbdelFattah A A, El-sayed M I, El-sayed F A, (2006): Protective effects of the antioxidant Gingko Biloba extract and the protease inhibitor a protinin against Leiurus quinquestriatus scorpion venom induced tissue damage in rats. J.Venom. Anim. Toxin Incl. Trop. Dis., 12: 255 - 275.

Fatani A J, Amany A E, Rabab M A, Nozha A A, Amal Q D, (2010): Comparative study between the protective effects of Saudi and Egyptian antivenoms, alone or in combination with ion channel modulators, against deleterious actions of Leiurus quinquestriatus scorpion venom. Toxicon., 55: 773 - 786 .

Finney D J, (1964): In statistical Method in biological assay, Charles Criffin and Company Limited, London, 528.

Fischer F G, Bohn H, (1957): The toxins of the Brazilian scorpions, Tityus serrulatus and Tityus bahiensis. Physiol. Chem., 306: 269 - 272.

Gallacci M, Nascimento N, Rogero J R, Vassileff V S, (2000): Influence of temperature upon effects of crotoxin and gamma-irradiated crotoxin at rat neuromuscular transmission. Toxicol Lett., 114: 77 -80 .

Garrison W M, (1987): Reaction mechanisms in the radiolysis of peptides, polypeptides, and proteins. Chem. Rev., 87: 381 - 398.

Gutierrez J M, Lomonte B, (1995): Phospholipase $\mathrm{A}_{2}$ myotoxins from Bothrops snake venoms. Toxicon., 33: 1405 - 1424.

Halliwell B D, Gulteridge J M C, (1989): The chemistry of oxygen radicals and other oxygen derived species. Free Radicals in Biology and Medicine. Clarendon Press, New York, 543.

Halliwell B D, Gulteridge J M C, (1990): Free Radicals in Biology and Medicine. Clarendon Press, Oxford.

Hayes A, Francis, (2001): Principle and methods of toxicological $4^{\text {th }}$ edition edited by a.Wallace Hayes, taylor and francis, 1039 - 1084.

Henriques M C, Gazzinelli G, Diniz C R, Gomez M V, (1968): Effect of the venom of scorpion Tityus serrulatus on adrenal gland catecholamines. Toxicon, 5: 175 - 179.

Hunter W M, Greenwood F C, (1962): The most widely used radio-iodination technique, Nature, 194: 495 - 496.

Ibrahim A, Al-Jammaz A H, (2003): Physiological Effects of $\mathrm{LD}_{50}$ of Echis coloratus Crude Venom on Rat at Different Time Intervals. J. King Saud Univ., Vol. 15, Science (2), 135 - 143.

International Federation of Clinical Chemistry (IFCC) methods for the measurement of catalytic concentration of enzymes, (1989): Part 7: IFCC method for creatine kinase, JIFCC; 1: 130 $-139$.

Kini R M, (1997): Venom phospholipase $A_{2}$ a complete multifunction protein puzzle. In: Kini $\mathrm{R}$ $\mathrm{M}$ editor, venom phospholipase $\mathrm{A}_{2}$ enzymes, structure, function and mechanism, wiley, chichester., 1 - 28.

Knust E J, Dutschka K, Machulla H J, (1990): J.Radioanal. Nucl. Chem. Lett., 144: 107 - 113.

Levine R A, Pesch L A, Klatskin G, Giarman N J, (1964): Effect of serotonin on glycogen metabolism in isolated rat liver. J. Clin . Invest., 43: 797 - 809.

McFarlane A S, (1958): Efficient trace-labelling of proteins with iodine, Nature (London), 182: 36 53.

Meister A, Anderson M E, (1983): Glutathione. Annu. Rev. Biochm., 52: 711 - 760.

Minton, Sherman A, (1974): Venom diseases. Thomas. 235 - 246.

Milan Bier, (1959): Electrophoresis, theory, methods and applications. Academic Press Inc (London) LTD. New York 3, N.Y, 179.

Mohamed A H, Hani-Ayobe M, Beskharoun M A, EL-damarawy N A, (1972): Glycemic responses to scorpion venom. Toxicon., 10: 139 149. 

National Cholesterol Education Program (NCEP) Recommendation of High-Density Lipoprotien Cholesterol, (1995): Executive Summary. Clin Chem., 41: 1427 - 1433.

Nigam S, Schewe T, (2000): Phospholipase $A_{2}$ and lipid peroxidation. Biochem Biophys Acta., 1488: $167-181$.

Ouchterlony O, (1948): Invitro method for testing the toxin production capacity of diphtheria bacteria. actapath. Microbial. Scand., 25: 186 - 191.

Ray D, Sharatchandra K, Thokchom I, (2006): Antipyretic, antidiarrhoeal, hypoglycaemic and hepatoprotective activities of ethyl acetate extract of Acacia catechu Willd in albino rats. Indian J. Pharmacol., 38 (6): 408 - 413.

Rayudu G V S, (1983): Radiotracers for medical application, CRS series in Radiotracers in Biology and Medicine vol.11: 110 - 119.

Rhodes B A, (1974): Considerations in the radiolabeling of albumin. Sem. Nucl. Med., 4: 281 $-293$.

Rogers J C, Qu Y, Tanada T N, Scheuer T, Catterall W A, (1996): Molecular determinants of high affinity binding of alpha scorpion toxin and sea anemone toxin in the S3-S4 extracellular loop in domain IV of the $\mathrm{Na}^{+}$channel alpha subunit.J. Biol.Chem., 271: 15950 - 15962.

Rogero J R, Nascimento N, (1995): Detoxification of snake venom using ionizing radiation. J. Venom. Anim. Toxins., 1: 7 - 10.

Saccavini J C, Bruneau C, IAEA, (1984): Radiolabeling of thioguanine with. ${ }^{125} \mathrm{I}$ for diagnosis and therapy: in vitro and in vivo evaluation. $\mathrm{CN}$., 4519: 153 - 158.

Sevanian A, Written M I, Mcleod I I, Kim E, (1989): Lipid peroxidation and phospholipase $A_{2}$ activity in liposomes composed of unsaturated phospholipids: a structural basis for enzyme activation. Biochem. Biophs. Acta., 961: 316 - 327.

Shaaban E A, (1990): Study on Impact of Irradiation Treatment on Pharmacological Responses of Scorpion Venom and Antivenom Serum, Ph.D Thesis, Cairo University.

Shaaban E A, (2003): Influence of ionizing radiation on cobra venom (Naja haje) and cerastes cerastes venoms: Toxicological and Immunological aspect. The Egyptian Journal of Hospital Medicine 13: 99 - 111.

Shaaban E A, Hafez M N, (2003): Ability of gamma-irradiated polyvalent antivenin to neutralize the toxicity of the Egyptian Cobra (Naja haje) venom. The Egyptian Journal of Hospital medicine 13: 135 - 152.

Skalka M, Antoni F, (1970): Effect of radiation on the biological properties of proteins. In: Radiation Sensitivity of toxins and animal poisons. Proceeding of a Panel on the Radiation Sensitivity of Toxins and Animal Poisons organized by the IAEA in Bangkok, $1-13$.

Sofer S, Shahak E, Slonim A, Gueron M, (1991): Myocardial injury without heart failure following envenomation by the scorpion Leiurus quinquestriatus in childern. Toxicon., 29: 382 385.

Souza $\mathbf{F}$ A, Spencer $\mathbf{P} \mathbf{J}$, Rogero $\mathbf{J} \mathbf{R}$, Nascimento N, Dal Pai-Silva $M$, Gallacci $M$, (2002): ${ }^{60} \mathrm{Co}$ gamma irradiation prevents Bothrops jararacussu venom neurotoxicity and myotoxicity in isolated mouse neuromuscular junction. Toxicon., 40: 1101 - 1106.

Tietz N W, (1976): Fundamentals of Clinical Chemistry W.B. Saunders CO, Philadelphia, London, Toronto, 245 - 247.

Werness, Hope B, (2004): The Continuum Encyclopedia of Animal Symbolism in art. Continuum International Publishing Group. 476.

Yang C C, (1970): Structure Activity Relationship and Immunochemical studies on Corbotoxin. In: Radiation Sensitivity of Toxins and Animal Poisons. Proceedings of a Panal on the Radiation Sensitivity of Toxins and Animal Poisons organized by the IAEA, Banckok., 63 - 74.

Yoshioka T, Kawada K, Shimada T, Mori M, (1979): Lipid peroxidation in maternal and cord blood and protective mechanism against activated oxygen toxicity in the blood. Am. J. Obstet. Gynecol., 135 (3): 372 - 376.

Zlotkin E, Miranda F, Rochat H, (1978): Chemistry and pharmacology of Buthinae scorpion venoms. In: Bettini, S. (Ed.), Handbook of Experimental Pharmacology, Arthropod Venoms, 48. Springer Varlag, Berlin, 317 - 36. 
Table (1): LD $_{50}$ for Native, 1.5 KGy and 3 KGy Gamma Irradiated L.q Scorpion Venom:

\begin{tabular}{|c|c|}
\hline Venom & LD $_{\mathbf{5 0}}(\mathbf{m g} / \mathbf{k g})$ \\
\hline Native (non-irradiated) L.q & 0.394 \\
\hline Irradiated (1.5 KGy) L.q & 3.517 \\
\hline Irradiated (3 KGy) L.q & 7.500 \\
\hline
\end{tabular}

Mice were classified into groups each included 6 animals to be used for determination of $\mathrm{LD}_{50}$ for native and gamma irradiated (1.5 KGy and $3 \mathrm{KGy}$ ) Leiurus quinquestriatus scorpion venom.

Table (2): The In-Vitro Stability of ${ }^{125}$ I-Venom:

\begin{tabular}{|c|c|c|}
\hline Time post labeling (hour) & ${ }^{125} \mathrm{I}-\mathrm{SV} \%$ & Free iodine \% \\
\hline 1 & $95.8 \pm 1.7$ & $3.2 \pm 0.3$ \\
\hline 2 & $95.0 \pm 1.2$ & $4.0 \pm 0.3$ \\
\hline 4 & $94.3 * @ \pm 1.3$ & $5.7 \pm 0.2$ \\
\hline 8 & $93.7 * @ \pm 1.3$ & $6.3 \pm 0.1$ \\
\hline 12 & $91.9 * @ \pm 1.6$ & $7.1 \pm 0.2$ \\
\hline 24 & $90.3^{*} @ \pm 0.9$ & $9.7 \pm 0.3$ \\
\hline
\end{tabular}

Mean \pm S.D. (mean of three experiments) $\quad, \quad *$ Significant difference from Normal group $(\mathrm{p}<0.05)$ @ Significant difference from preceding value $(\mathrm{p}<0.05)$

Table (3): Biodistribution Pattern of ${ }^{125}$ I-Venom in Different Organ or Body Fluids in Normal Mice (n=3) at Different Times.

(a):

\begin{tabular}{|c|c|c|c|c|}
\hline \multirow{2}{*}{$\begin{array}{l}\text { Whole organs or body } \\
\text { fluid }\end{array}$} & \multicolumn{4}{|c|}{$\begin{array}{c}\%^{125} \text { I- L.q venom distribution /organ or body fluid at } \\
\text { different times post injection }\end{array}$} \\
\hline & $10 \mathrm{~min}$ & 1h & $2 h$ & 4h \\
\hline Blood & $28.5 \pm 2.3$ & $20.8 \pm 1.5$ & $12 \pm 0.8$ & $5.8 \pm 0.2$ \\
\hline Bone & $3.3 \pm 0.2$ & $2.9 \pm 0.2$ & $2.1 \pm 0.1$ & $1.8 \pm 0.1$ \\
\hline Muscle & $3.1 \pm 0.3$ & $4.5 \pm 0.4$ & $3.7 \pm 0.2$ & $1.1 \pm 0.1$ \\
\hline Brain & $1.4 \pm 0.2$ & $1.2 \pm 0.1$ & $0.9 \pm 0.2$ & $0.7 \pm 0.1$ \\
\hline Lungs & $1.9 \pm 0.1$ & $0.6 \pm 0.02$ & $0.5 \pm 0.02$ & $0.1 \pm 0.04$ \\
\hline Heart & $1.3 \pm 0.8$ & $0.2 \pm 0.01$ & $0.1 \pm 0.02$ & $0.04 \pm 0.001$ \\
\hline Liver & $10.4 \pm 0.1$ & $12.6 \pm 1.3$ & $10.5 \pm 1.3$ & $8.3 \pm 1.2$ \\
\hline Kidneys & $11.3 \pm 0.7$ & $29.08 \pm 0.4$ & $22.3 \pm 1.1$ & $11.6 \pm 0.9$ \\
\hline Spleen & $1.2 \pm 0.3$ & $0.28 \pm 0.01$ & $0.4 \pm 0.01$ & $0.2 \pm 0.01$ \\
\hline Intestine & $4.2 \pm 0.1$ & $9.4 \pm 1.4$ & $14.5 \pm 0.9$ & $14.9 \pm 2.3$ \\
\hline Urine & $6.2 \pm 0.9$ & $12.7 \pm 0.8$ & $16.5 \pm 0.8$ & $34.5 \pm 1.4$ \\
\hline
\end{tabular}

(b):

\begin{tabular}{|c|c|c|c|c|}
\hline \multirow{2}{*}{ Organ or body fluid (g) } & \multicolumn{4}{|c|}{$\%^{\mathbf{1 2 5}} \mathbf{I}-\mathbf{L . q}$ venom distribution /organ (g) or body fluid at } \\
& \multicolumn{3}{|c|}{ different times post injection } \\
\cline { 2 - 5 } & $\mathbf{1 0 m i n}$ & $\mathbf{1 h}$ & $\mathbf{2 h}$ & $\mathbf{4 h}$ \\
\hline & & & & \\
Brain & $3.5 \pm 0.5$ & $3.0 \pm 0.2$ & $2.2 \pm 0.4$ & $1.7 \pm 0.2$ \\
Blood & $16.3 \pm 0.9$ & $11.9 \pm 0.6$ & $6.9 \pm 0.3$ & $3.3 \pm 0.1$ \\
Brain/Blood & 0.2 & 0.25 & 0.32 & 0.52 \\
& & & & \\
\hline
\end{tabular}




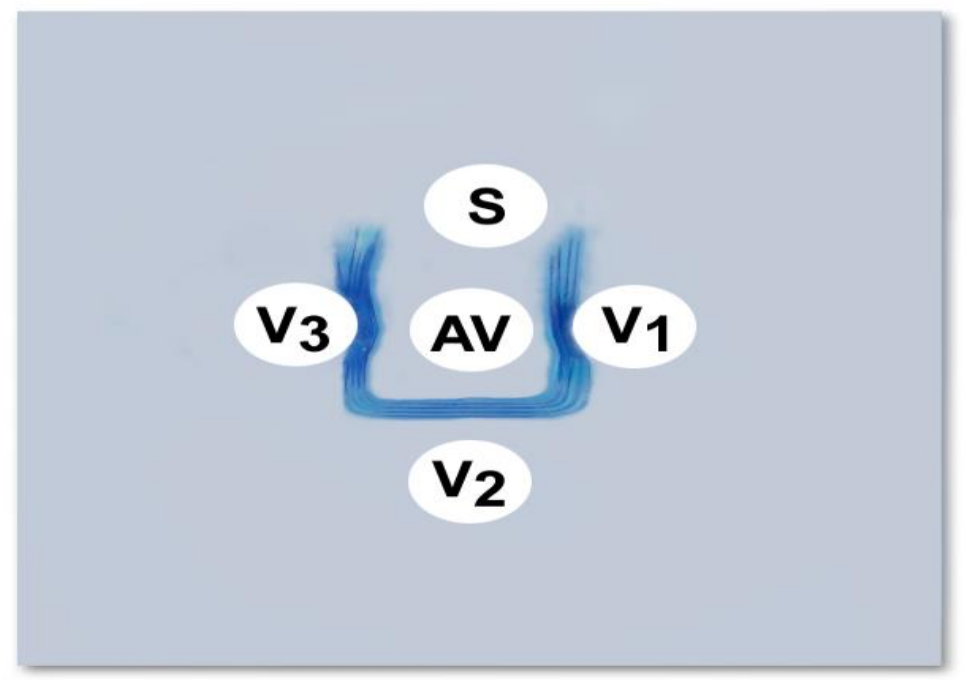

S: saline (upper well).

AV: polyvalent antivenin of scorpion venom (central well).

V1: native leiurus quinquestriatus scorpion venom (right well).

V2: irradiated (1.5 KGy) leiurus quinquestriatus scorpion venom (lower well).

V3: irradiated (3 KGy) leiurus quinquestriatus scorpion venom (left well).

Figure (1): Immunodiffusion Reaction of Horse Serum Polyvalent Antivenin with Native, 1.5 KGy \& 3 KGy $\gamma$-Irradiated L.q Scorpion Venom.

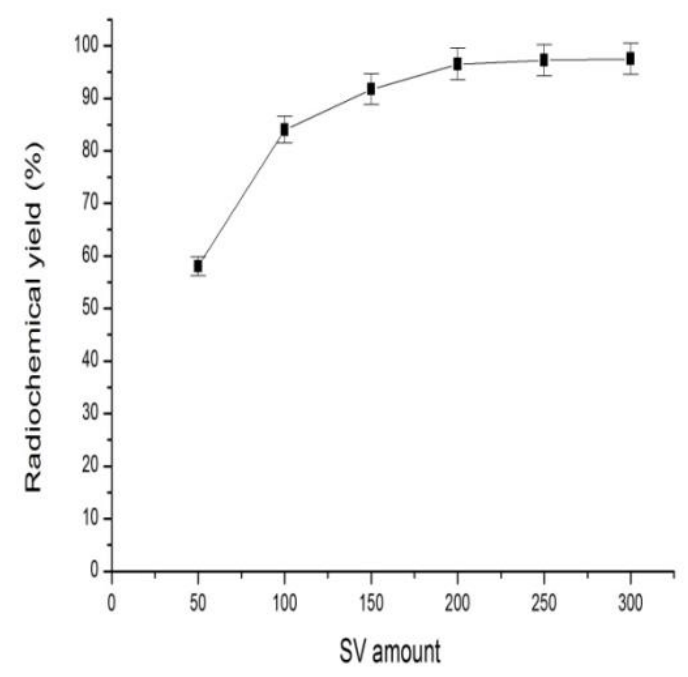

Figure (2): Radiochemical Yield of ${ }^{125} \mathrm{I}-\mathrm{SV}$ as a Function of SV Amount.

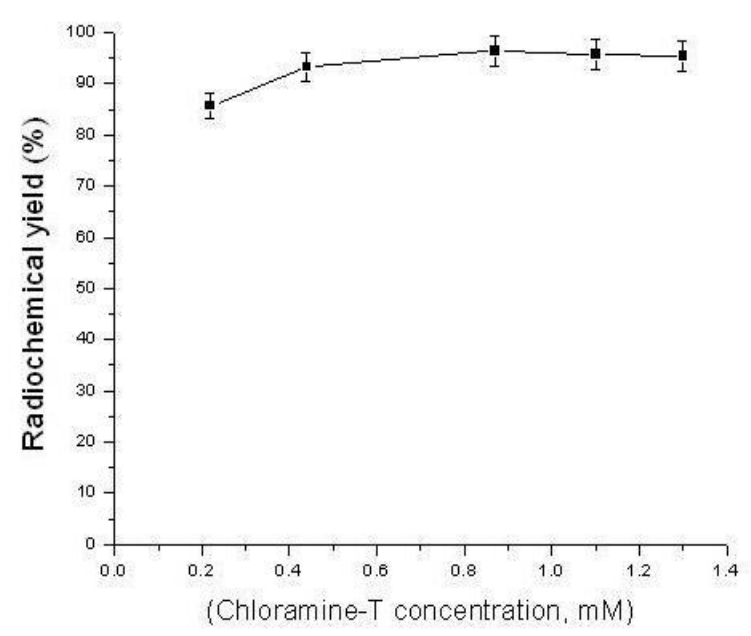

Figure (3): Radiochemical Yield of ${ }^{125} \mathrm{I}-\mathrm{SV}$ as a Function of Chloramine-T Concentration. 
Modulation of the.....

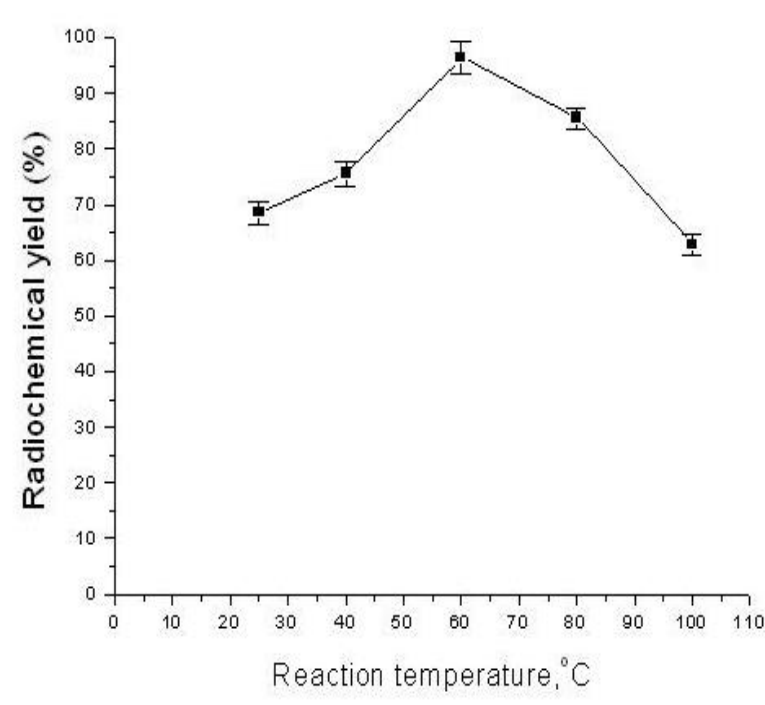

Figure (4): Radiochemical Yield of ${ }^{125} \mathrm{I}-\mathrm{SV}$ as a Function of Reaction Temperature.

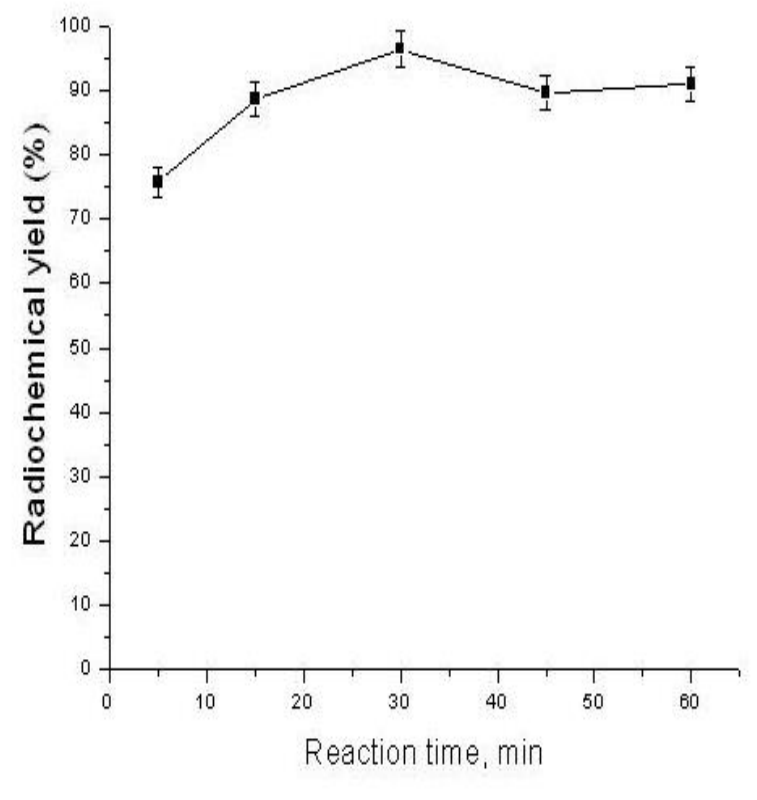

Figure (5): Radiochemical Yield of ${ }^{125} \mathrm{I}-\mathrm{SV}$ as a Function of Reaction Time.

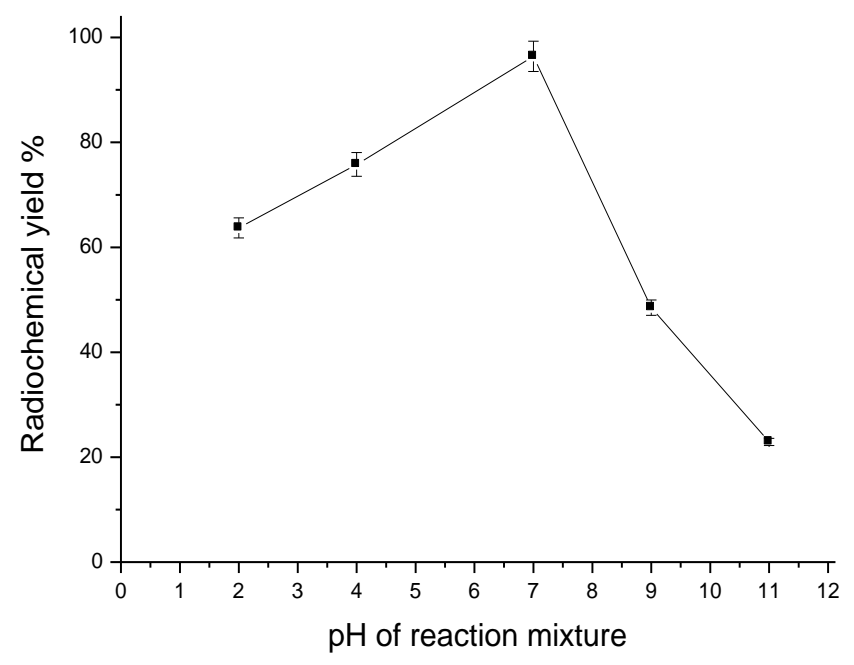

Figure (6): Radiochemical yield of ${ }^{125} \mathrm{I}$ - scorpion venom as a function of $\mathrm{pH}$ of reaction mixture. 


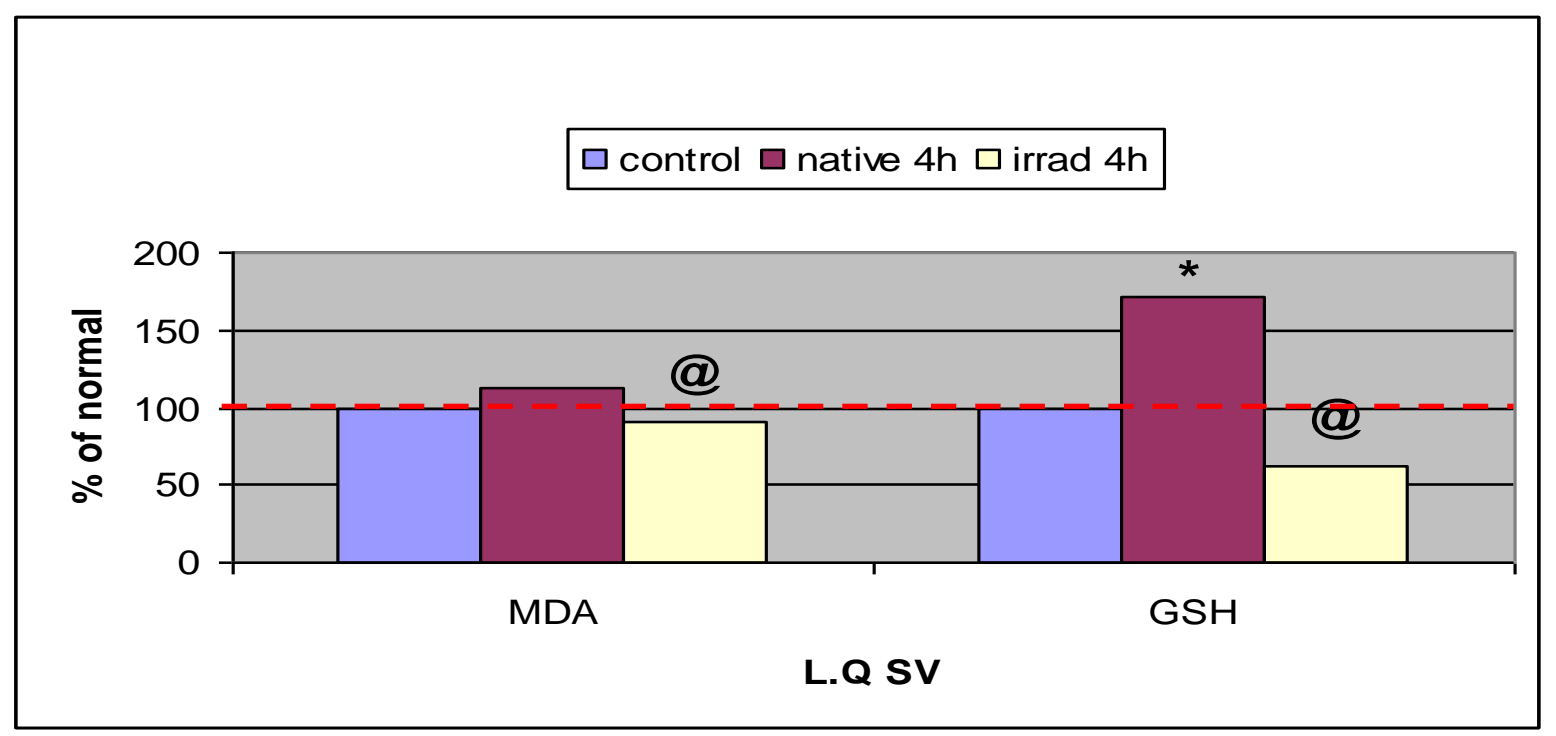

Figure (7): Effect of Native and Gamma Irradiated (1.5 KGy) Leiurus quinquestriatus Scorpion Venom (L.Q SV) on Plasma MDA, Blood GSH in Rats.

Statistical analysis was carried out by one-way ANOVA followed by Tukey-Kramer multiple comparisons test:

* Significant difference from Normal group $(\mathrm{p}<0.05)$

@ Significant difference from Native L.q group $(\mathrm{p}<0.05)$

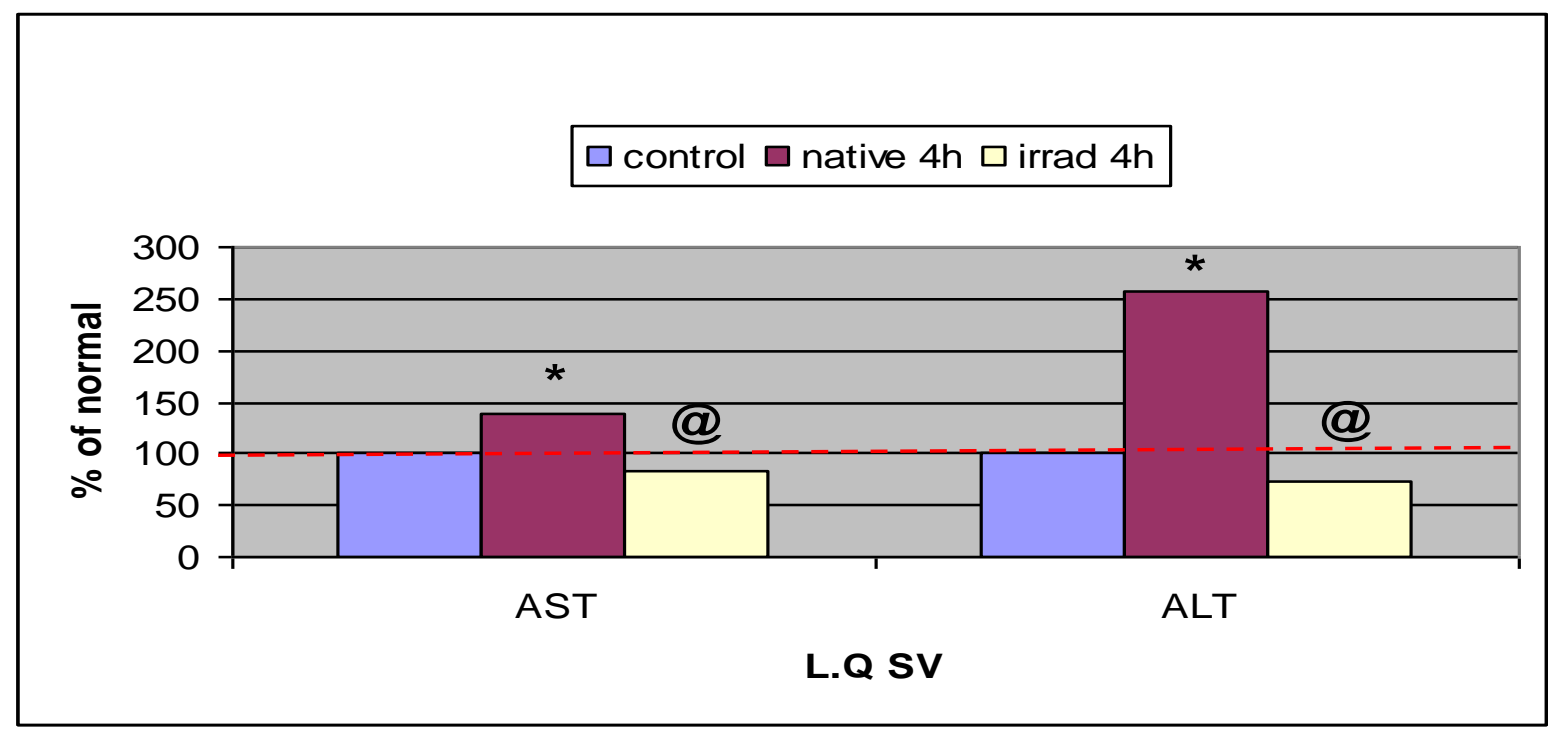

Figure (8): Effect of Native and Gamma Irradiated (1.5 KGy) Leiurus quinquestriatus Scorpion Venom (L.Q SV) on Serum Aspartate Aminotransferase (AST) and Alanine Aminotransferase (ALT) Activity in Rats.

Statistical analysis was carried out by one- way ANOVA followed by Tukey-Kramer multiple comparisons test:

* Significant difference from Normal group $(\mathrm{p}<0.05)$.

@ Significant difference from Native L.q group $(\mathrm{p}<0.05)$. 



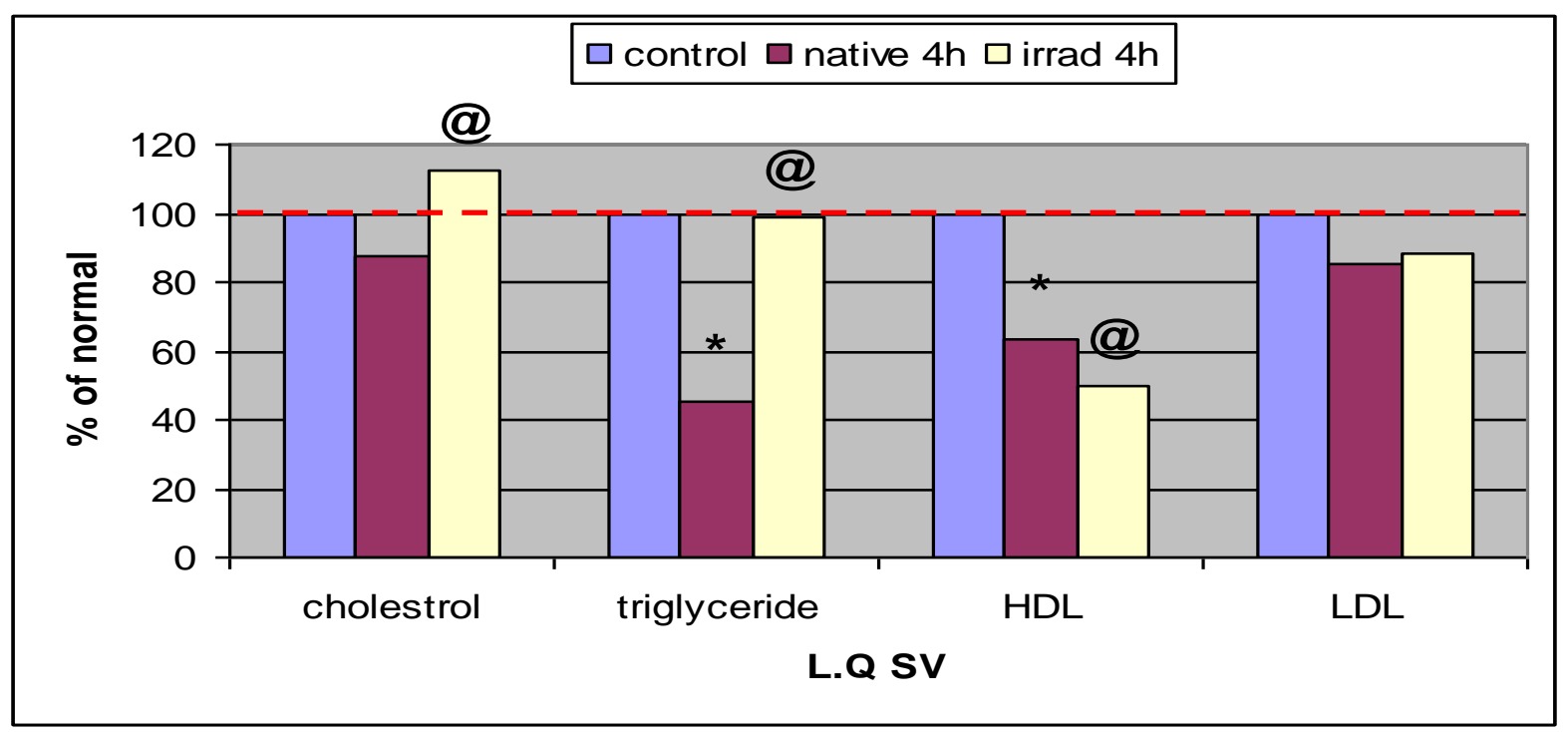

Figure (9): Effect of Native and Gamma Irradiated (1.5 KGy) Leiurus quinquestriatus Scorpion Venom (L.Q SV) on Serum Lipid Profile (Cholesterol, Triglyceride, HDL, LDL) in Rats.

Statistical analysis was carried out by one- way ANOVA followed by Tukey-Kramer multiple comparisons test.

* Significant difference from Normal group $(\mathrm{p}<0.05)$.

@ Significant difference from Native L.q group $(\mathrm{p}<0.05)$.

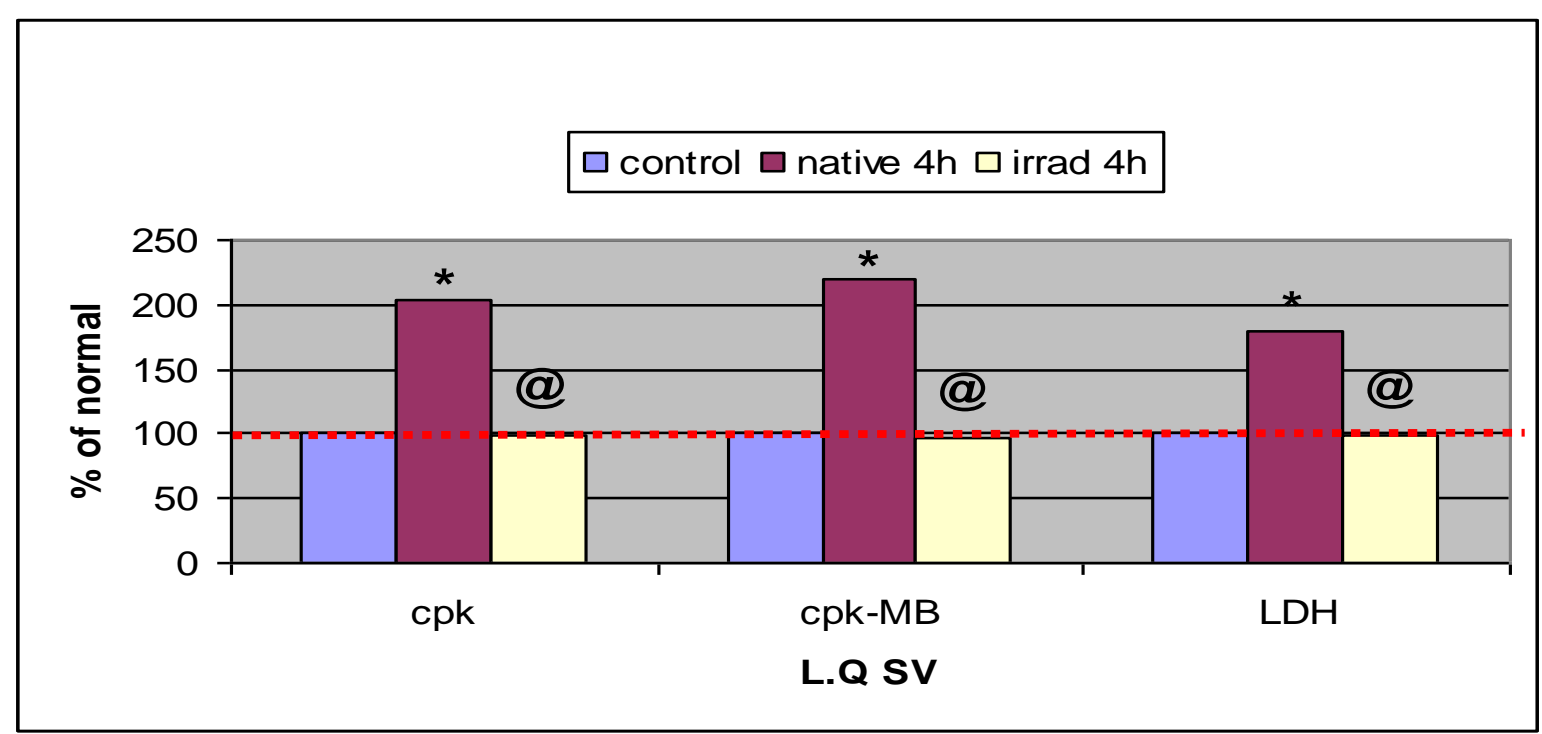

Figure (10): Effect of Native and Gamma Irradiated (1.5 KGy) Leiurus quinquestriatus Scorpion Venom (L.Q SV) on Serum Cardiac Enzyme (CK, CK-MB, LDH) Activity in Rats.

Statistical analysis was carried out by one- way ANOVA followed by Tukey-Kramer multiple comparisons test:

* Significant difference from Normal group $(\mathrm{p}<0.05)$.

@ Significant difference from Native L.q group $(\mathrm{p}<0.05)$. 


\section{تعديل التاثيرات الفارماكولوجية والبيوكيميائية لسم العقربة الصفراء (اللورس التوسئ

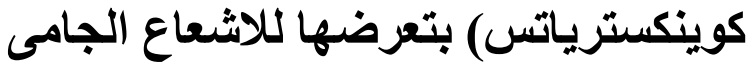

هبة عبد المنعم محمد*: عصمت عبد السلام شعبان*:عبير محمد امين**: سناء عبد الباقى قناوى

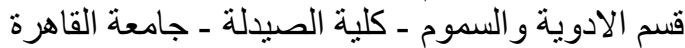

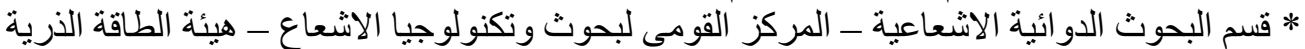

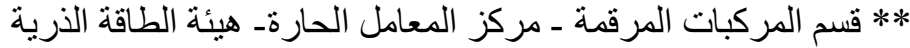

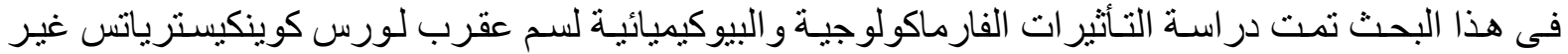

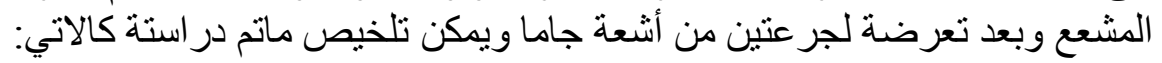

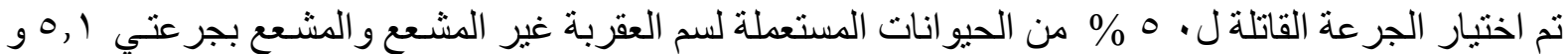

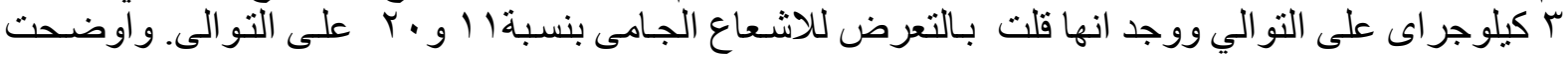

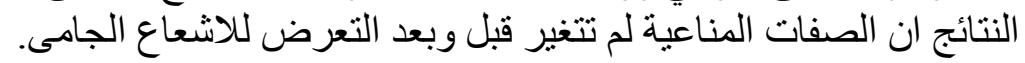

و عند حقن الفئران بسم لورس كوينكسترياتس الخام وجد زيادة في تكوين الدلالات الحيوية للاجهاد التاكسدى

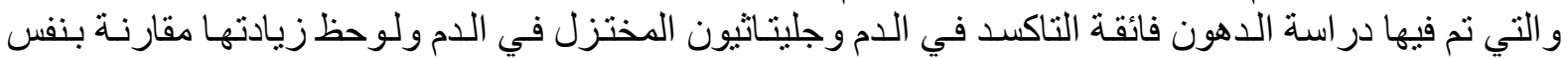
الجرعة من السم المشعع (1, 1 كيلوجر ایى) بالمقارنة بالمجموعة الضابطة .

لوحظ ارتفاع معدل كلا من: انزيم الانين تر انس امينيز (ALT) و الاسبرتيت ترانس امينيز (AST) :

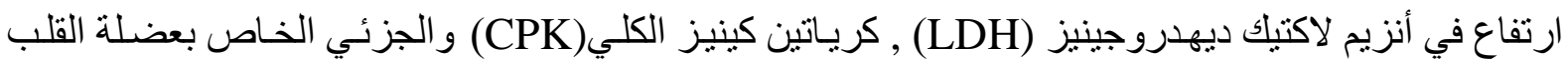
(CPK-MB) الشعع (1, كيلوجر اى) بالمقارنة بالمجمو عة الضابطة .

حدث انخفاضا ملحوظا فى معدلات كل من جليسيرات الثناثية و البروتينات الدهنية عالية الكثافة (HDL). تم ترقيم سم العقربة الصفراء لورس كينكيسترياتس باليود المشع فى الظروف المثلى للترقيم من حيث تركيز

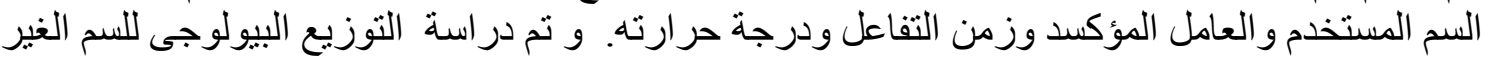

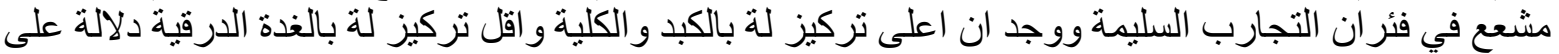

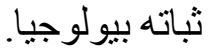

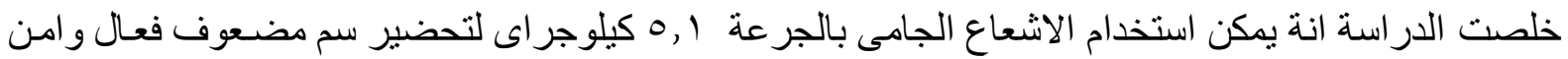
من الناحية السمية و المناعية كبديل لاستخدام السم الخام فى الخيول للحصول على على مصل مضاد امن. 